\title{
Program Pencegahan Penularan COVID-19 pada Komunitas Ibu Rumah Tangga dengan HIV di Surabaya
}

\author{
Hanna Tabita Hasianna Silitonga ${ }^{1}$, Etha Rambung ${ }^{1}$, Romauli Nainggolan ${ }^{2}$, Gusto Benyamin \\ Messakh $^{1}$, Keith Justine Thiotansen ${ }^{1}$ \\ ${ }^{1}$ Departemen Kedokteran Fakultas Kedokteran, ${ }^{2}$ Departemen Manajemen Fakultas Ekonomi dan Bisnis, \\ Universitas Ciputra Surabaya CitraLand CBD Boulevard, Surabaya, 67219, Indonesia
}

\author{
ARTICLE INFO: \\ Received: 2020-08-27 \\ Revised: 2020-09-22 \\ Accepted: $2020-10-25$
}

\section{Keywords:}

COVID-19; Housewife; HIV; Prevention;

Transmission

\section{ABSTRACT}

Everyone was affected by COVID-19 pandemic, including housewives with HIV joined in Bu'Daya community. In management of COVID-19, patient's comorbid history was important because these patients could aggravate the condition of COVID-19. HIV was a chronic disease related to the immune system. Therefore, it was important for people with HIV to prevent infection of COVID-19. The problem faced by this community regarding COVID-19 was knowledge and attitudes of community members was not known yet. Therefore, efforts were needed to find out and improve understanding of COVID-19. The solution offered to this community was training and assistance regarding the prevention of COVID-19 through the "We Are Empowered, We Prevent Covid-19 Transmission" Program. This program was part of a series of "We Are Empowered" programs, a service program of the Empower Woman with HIV, in Surabaya. The aim of this program was to increase knowledge and attitudes of the participants towards preventing the transmission of COVID-19. The implementation method was by community education, training and community assistance. The results obtained from this community service were the increased knowledge and attitudes of the participants regarding the behavior of preventing the transmission of COVID-19 which could be seen from the pre and post-test results.

(c) 2020 Published by University of Merdeka Malang. This is an open access article distributed under the CC BY-SA 4.0 license (https://creativecommons.org/licenses/by-sa/4.0/)

How to cite: Silitonga, H. T. H., Rambung, E., Nainggolan, R., Messakh, G. B., \& Thiotansen, K. J. (2020). Program Pencegahan Penularan COVID-19 pada Komunitas Ibu Rumah Tangga Dengan HIV di Surabaya. Abdimas: Jurnal Pengabdian Masyarakat Universitas Merdeka Malang, 5(3), 193-201. https://doi.org/10.26905/abdimas.v5i3.4844

\section{PENDAHULUAN}

Angka penyakit akibat Human Immunodeficiency Virus (HIV) di Indonesia mengalami peningkatan yaitu dari 46.659 kasus pada tahun 2018 menjadi 50.282 kasus pada tahun 2019 ((Kementerian Kesehatan Republik Indonesia, 2020). Dari perolehan data tersebut, provinsi dengan jumlah kasus baru HIV terbanyak 
ABDIMAS: Jurnal Pengabdian Masyarakat Universitas Merdeka Malang

Volume 5, No 3, November 2020: 193-201

adalah Jawa Timur sebanyak 8935 kasus dan disusul dengan DKI Jakarta sebanyak 6701 kasus. Jika dilihat dari jenis kelamin, maka perbandingan antara orang dengan HIV (ODH) laki-laki dan perempuan di Jawa Timur tidak terlalu jauh berbeda yaitu sebesar 1.4:1 dimana laki-laki sebanyak 5148 dan perempuan sebesar 3787 kasus.

Salah satu penyebab tingginya angka HIV pada perempuan adalah melalui hubungan seksual. Dalam dinamika penularan infeksi menular seksual (IMS) termasuk HIV, jalur penularannya melibatkan populasi antara (bridging population). Populasi antara ini menjadi jalan masuk infeksi dari populasi inti (kunci) kepada populasi umum (Direktorat Jenderal Pengendalian Penyakit dan Penyehatan Lingkungan, 2016). Hal ini nyata terjadi jika laki-laki (populasi antara) menggunakan jasa wanita pekerja seks langsung/ tidak langsung (populasi kunci) dan kemudian menularkan IMS/HIV kepada istrinya yang adalah ibu rumah tangga dan ibu ke anaknya (populasi umum). Jalur inilah yang menyebabkan semakin banyak ditemukan kejadian HIV pada ibu rumah tangga atau anak-anak.

Komunitas Bu'Daya (Ibu Berdaya) adalah salah satu komunitas ibu rumah tangga dengan HIV di Surabaya, Jawa Timur. Komunitas ini diinisiasi oleh salah seorang ibu yang mendapatkan virus HIV dari suaminya yang memiliki perilaku berisiko berganti-ganti pasangan seksual. Setelah mengetahui kondisinya yang mengidap HIV, ia pun mendapatkan banyak informasi dan pelatihan dari salah satu lembaga swadaya masyarakat (LSM) HIV/AIDS di Surabaya. Sejak itu, ibu tersebut aktif untuk menjadi pendukung sebaya bagi sesama penderita HIV. Banyak contoh yang menunjukkan keberdayaan seorang penderita HIV setelah mendapatkan informasi yang memadai (Silitonga 2018). Oleh sebab itu, penting sekali untuk penderita HIV menjadi berdaya agar dapat melanjutkan hidupnya seperti layaknya orang normal dan memutus rantai penularan HIV kepada anak, pasangan dan lainnya. Hal ini dicapai melalui adanya Kelompok Dukungan Sebaya (KDS). Kelompok dukungan yang ada di Puskesmas selama ini merupakan kelompok dukungan sebaya untuk umum dan bukan khusus ibu rumah tangga, sehingga para ibu mengalami sedikit kesulitan untuk terbuka dan bercerita tentang kondisi mereka. Mulai tahun 2018, komunitas ini dibentuk atas dasar keinginan untuk mendampingi penderita HIV khususnya ibu rumah tangga (Gambar 1).

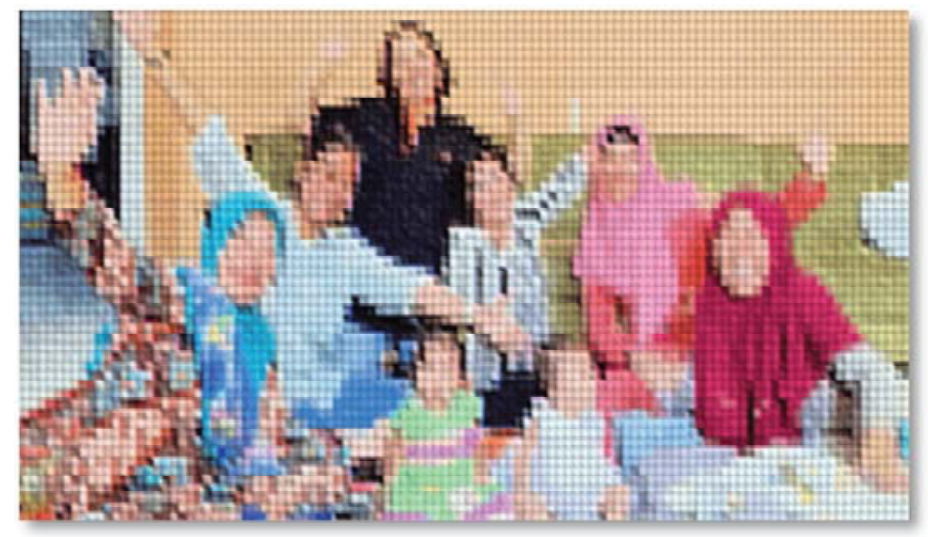

Gambar 1. Anggota komunitas bersama dengan Tim Pelaksana Pengabdian Masyarakat (foto sengaja disamarkan untuk menjaga kerahasiaan identitas)

Saat ini, Indonesia tengah mengalami berbagai permasalahan terkait COVID-19. Virus SARS-CoV-2 Penyakit ini disebabkan oleh virus SARS-CoV-2 yang merupakan keluarga dari coronavirus (Ditjen PP \& PL 
Program Pencegahan Penularan COVID-19 pada Komunitas Ibu Rumah Tangga dengan HIV di Surabaya

Hanna Tabita Hasianna Silitonga, Etha Rambung, Romauli Nainggolan, Gusto Benyamin Messakh, Keith Justine Thiotansen

Kemenkes RI, 2020). Virus ini dapat bertahan di permukaan benda-benda dari plastik dan stainless steel sampai 72 jam. Penularan virus ini dapat melalui kontak langsung misalnya droplet, atau tidak langsung misalnya menyentuh benda-benda yang terkontaminasi oleh virus (Ditjen PP \& PL Kemenkes RI, 2020). Selain itu, sejak bulan Juli 2020, WHO menyatakan ada kemungkinan penularan melalui udara khususnya di tempat-tempat yang tertutup tanpa ventilasi yang memadai dengan waktu yang cukup lama bersama dengan orang yang terinfeksi, serta tidak diterapkannya cuci tangan dan penggunaan masker (WHO, 2020).

Dalam manajemen klinis COVID-19, riwayat komorbid pasien adalah penting karena pasien dengan penyakit penyerta dapat memperberat kondisi COVID-19 dan memiliki prognosis penyakit yang buruk. Beberapa kondisi komorbid diantaranya adalah Diabetes Mellitus, penyakit terkait geriatri, penyakit ginjal, penyakit terakit autoimun dan penyakit kronis lainnya (Ditjen PP \& PL Kemenkes RI 2020). HIV merupakan salah satu penyakit kronis yang berkaitan dengan sistem imun. Studi literatur yang telah dilakukan menemukan bahwa Orang dengan HIV (ODH) rentan untuk terkena penyakit COVID-19 (Chenneville et al., 2020), walaupun ada penelitian juga yang menyatakan sebaliknya (Etienne et al., 2020; Laurence, 2020). Bagaimanapun juga, kemungkinan bahwa orang dengan HIV yang tidak mengonsumsi obat antiretrovirus (ARV) secara rutin, lebih rentan untuk terkena infeksi oportunistik termasuk COVID-19, tidak dapat diabaikan.

Komunitas Bu'Daya (Ibu Berdaya) adalah komunitas khusus ibu rumah tangga yang terinfeksi HIVAIDS di Kecamatan Tandes, Surabaya. Komunitas ini beranggotakan enam orang ibu rumah tangga (IRT) yang berdomisili di sekitar Kecamatan Tandes. Komunitas ini biasanya berkumpul di salah satu rumah anggota di Kecamatan Tandes. Pada masa pandemi ini, komunitas ini jarang berkumpul tetapi tetap berkomunikasi melalui grup whatsapp. Dari wawancara dan situasi terkini yaitu pandemi, beberapa permasalahan yang diperoleh dari komunitas ibu rumah tangga dengan HIV yang terkait COVID-19 adalah tidak diketahuinya pengetahuan dan sikap para ibu rumah tangga terkait penyakit ini. Memang tidak dapat dipungkiri, COVID-19 adalah penyakit baru yang belum dapat dimengerti sepenuhnya, akan tetapi pengetahuan dasar tentang pencegahan dan penularan COVID-19 penting untuk menurunkan insiden penyakit ini di Indonesia. Oleh sebab itu diperlukan upaya untuk mengetahui dan meningkatkan pemahaman akan COVID-19 termasuk mengenai pencegahan penularannya seperti penggunaan masker yang benar, cuci tangan dengan sabun dan air mengalir dan jaga jarak. Masalah lainnnya adalah kekhawatiran tentang obat ARV yang habis digunakan untuk pengobatan COVID-19. Hal ini disampaikan khususnya oleh para ibu yang bekerja di LSM. Hal ini karena pengobatan COVID-19 belum jelas dan pengobatan dengan obatobatan antiretrovirus digunakan dalam beberapa kasus walaupun belum terbukti secara ilmiah. Oleh sebab itu, para ibu perlu diberikan pemahaman mengenai hal ini agar tetap mengambil obat secara rutin dan tidak khawatir atau kehilangan kepercayaan terhadap sistem layanan kesehatan saat ini. Selain itu, penting untuk memberikan pemahaman minum obat ARV secara rutin untuk menekan jumlah virus di dalam tubuh penderita dan meningkatkan sistem kekebalan tubuh.

Solusi yang ditawarkan kepada komunitas ini adalah pelatihan dan pendampingan mengenai pencegahan penularan COVID-19 melalui Program "Kita Berdaya, Kita Cegah Penularan COVID-19". Program ini merupakan salah satu seri dari program serial "Kita Berdaya" yaitu program pengbadian masyarakat PKM Komunitas Bu'Daya (Ibu Berdaya dengan HIV) Surabaya yang didanai oleh DRPM Kemenristekdikti. Tujuan dari program ini adalah peningkatan pemahaman yaitu pengetahuan dan sikap dari para peserta terhadap pencegahan penularan COVID-19. 
ABDIMAS: Jurnal Pengabdian Masyarakat Universitas Merdeka Malang

Volume 5, No 3, November 2020: 193-201

\section{METODE}

Keseluruhan Pengabdian masyarakat ini dilakukan dalam kurun waktu 8 bulan, mulai dari tahap persiapan, pelaksanaan, evaluasi dan menghasilkan luaran. Khusus untuk pencegahan penularan COVID19, dilakukan selama 2 bulan pertama. Metode pelaksanaannya adalah dengan pendidikan masyarakat, pelatihan dan pendampingan melalui Whatsapp Group (WAG).

\section{Pendidikan Masyarakat.}

Pendidikan masyarakat yang dilakukan adalah dalam bentuk seminar yang tujuannya adalah meningkatkan pengetahuan dan sikap para peserta terhadap COVID-19 dan pencegahan penularan COVID19. Situasi pandemi menyebabkan kegiatan ini dilakukan dalam bentuk daring dengan memanfaatkan aplikasi Zoom (Gambar 2). Seminar ini dilakukan pada hari Kamis, 13 Agustus 2020, dari pukul 18.3020.30. Kegiatan ini diawali dengan pretest sebanyak 9 pertanyaan. Waktu yang diberikan untuk pre-test adalah 10 menit. Pre-test diberikan dalam bentuk google form yang dikirimkan melalui WAG. Pertanyaan yang diajukan terdiri dari 7 pertanyaan tentang pengetahuan dan 2 pertanyaan tentang sikap. Pertanyaan tentang pengetahuan meliputi kepanjangan singkatan COVID-19, penularan COVID-19, gejala COVID-19, pencegahan penularan COVID-19, pembagian zona COVID-19, jenis masker, cara menggunakan masker dengan benar. Pertanyaan tentang sikap meliputi penggunaan masker dan cuci tangan dengan sabun/ hand sanitizer.

Setelah memberikan pre-test, peserta diberikan materi seminar terkait COVID-19 dan bagaimana Orang Dengan HIV (ODH) menyikapi COVID-19. Materi seminar terkait COVID-19 meliputi karakteristik virus, metode penularan, gejala dan tanda, komorbid, kategori wilayah menurut COVID-19, pencegahan penularan, mengapa menggunakan masker, jenis masker, cara memakai masker dengan benar. Materi terkait sikap ODH terhadap COVID-19 meliputi kerentanan ODH, tindakan pencegahan ODH, penggunaan obat ARV pada ODH di masa pandemi COVID-19. Keseluruhan materi diberikan kurang lebih selama 90 menit. Setelah materi, dilakukan sesi diskusi atau tanya jawab selama 20 menit.
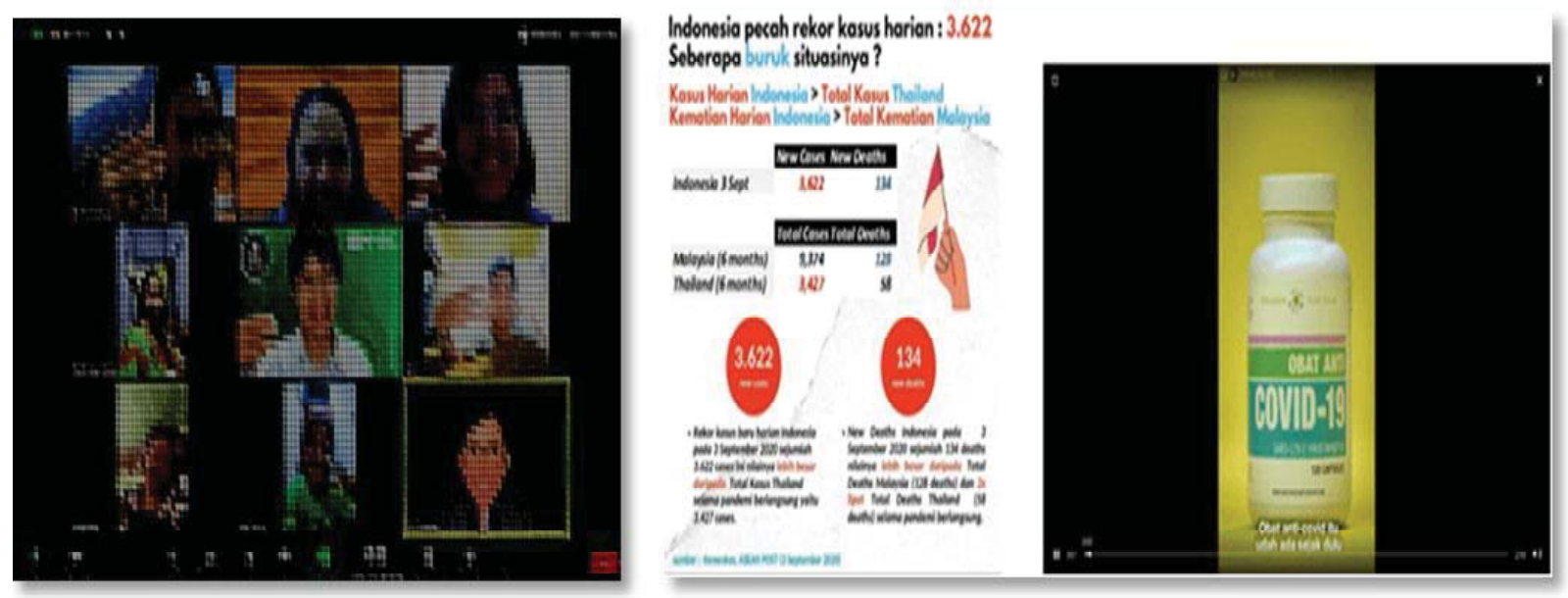

Gambar 2. Seminar melalui Zoom (foto disamarkan untuk menjaga kerahasiaan identitas)

Gambar 3. Poster infografis dan video obat anti COVID-19 
Program Pencegahan Penularan COVID-19 pada Komunitas Ibu Rumah Tangga dengan HIV di Surabaya

Hanna Tabita Hasianna Silitonga, Etha Rambung, Romauli Nainggolan, Gusto Benyamin Messakh, Keith Justine Thiotansen

\section{Pelatihan}

Pelatihan yang ditekankan dalam program ini adalah pemakaian Alat Pelindung Diri (APD) yaitu masker, face shield dan sarung tangan. Demonstrasi ditunjukkan melalui pada saat seminar melalui zoom dimana diperlihatkan terlebih dahulu jenis-jenis masker yaitu masker N95, masker bedah dan masker kain. Setelah itu pembawa materi mendemonstrasikan cara menggunakan masker tersebut dengan benar, mulai dari cara memasang, melepaskan dan membuang. Untuk masker kain, diinfokan bagaimana cara membersihkan sebelum digunakan ulang.

\section{Pendampingan melalui Whatsapp Group}

Pendampingan terkait pencegahan penularan COVID-19 dilakukan secara berkelanjutan melalui Whatsapp group. Tim pelaksana memancing dan mengingatkan kembali para peserta dengan cara mengirimkan informasi atau berita terkini mengenai COVID-19 dalam bentuk poster infografis atau video. Poster infografis yang digunakan diambil dari Instagram @pandemictalks dan video diunduh dari www.ceriterafightcovid19.com yang dimiliki oleh Edward Suhadi dengan judul Obat Anti COVID-19 yang juga dapat dilihat dari Instagram @edwardsuhadi. Baik poster dan video dibagikan ke WAG. Hal ini menyebabkan terjadi respon atau diskusi di dalam grup whatsapp. Tujuan dari pendampingan ini adalah penguatan materi yang diberikan melalui seminar dan meningkatnya pemahaman para peserta terhadap COVID-19.

Setelah dilakukan rangkaian kegiatan dalam program ini, maka dilakukan post test. Post test dilakukan dengan memberi pertanyaan sama seperti pre-test yaitu sebanyak 9 pertanyaan yang diberikan melalui google form. Para peserta dihimbau untuk mengerjakan apa adanya dengan tidak membuka sumber referensi. Hasil dari pre-test dan post-test selanjutnya dianalisa dengan menggunakan microsoft excell. Hasil disajikan dalam bentuk grafik yang membandingkan antara perolehan skor sebelum dan sesudah mengikuti program.

\section{HASIL DAN PEMBAHASAN}

Tujuan dari pengabdian masyarakat ini adalah meningkatkan pemahaman yaitu pengetahuan dan sikap para ibu rumah tangga dengan HIV terhadap COVID-19. Dari rangkaian kegiatan yang telah dilakukan maka diperoleh temuan sebagai berikut:

\section{Karakteristik Peserta}

Peserta dari program ini adalah ibu rumah tangga dengan HIV sebanyak 5 orang. Rentang umur dari para peserta adalah 23 sampai 44 tahun.

Tabel 1. Karakteristik peserta

\begin{tabular}{lcll}
\hline & Kode peserta & Usia (tahun) & \multicolumn{1}{c}{ Pekerjaan } \\
\hline KB01SC & 44 & LSM \\
KB02AL & 37 & Penjahit \\
KB03ST & 38 & Penjahit \\
KB04MA & 23 & LSM \\
KB05SR & 40 & IRT \\
\hline
\end{tabular}


ABDIMAS: Jurnal Pengabdian Masyarakat Universitas Merdeka Malang

Volume 5, No 3, November 2020: 193-201

\section{Peningkatan Pengetahuan dan Sikap Peserta}

Dari pre-test dan post-test yang diberikan, dilakukan analisa per butir pertanyaan yang dapat dilihat pada Tabel 2.

Tabel 2. Analisa per butir pertanyaan pre-test dan post-test peserta

\begin{tabular}{|c|c|c|c|c|c|}
\hline \multirow{2}{*}{\multicolumn{2}{|c|}{$\begin{array}{l}\text { No Pertanyaan } \\
\text { Pengetahuan }\end{array}$}} & \multicolumn{2}{|c|}{ Pre-Test } & \multicolumn{2}{|c|}{ Post-Test } \\
\hline & & n benar & \% benar & n benar & \% benar \\
\hline 1 & Apakah kepanjangan dari COVID-19? & 2 & 40 & 4 & 80 \\
\hline 2 & Bagaimana penularan COVID-19? & 5 & 100 & 5 & 100 \\
\hline 3 & Apa gejala COVID-19? & 0 & 0 & 5 & 100 \\
\hline 4 & $\begin{array}{l}\text { Bagaimana cara mencegah penularan } \\
\text { COVID-19? }\end{array}$ & 5 & 80 & 5 & 100 \\
\hline 5 & $\begin{array}{l}\text { Apa saja pembagian wilayah/zona untuk } \\
\text { COVID-19? }\end{array}$ & 3 & 60 & 5 & 100 \\
\hline 6 & Apa saja jenis masker? & 2 & 40 & 5 & 100 \\
\hline 7 & $\begin{array}{l}\text { Bagaimana cara menggunakan masker } \\
\text { dengan benar? }\end{array}$ & 5 & 100 & 5 & 100 \\
\hline Sikap & & n setuju & \% setuju & n setuju & \% setuju \\
\hline 1 & $\begin{array}{l}\text { Menurut anda, apakah penting meng- } \\
\text { gunakan masker keluar rumah? }\end{array}$ & 5 & 100 & 5 & 100 \\
\hline 2 & $\begin{array}{l}\text { Menurut anda, apakah penting sering } \\
\text { cuci tangan dengan sabun atau hand } \\
\text { sanitizer? }\end{array}$ & 4 & 80 & 5 & 100 \\
\hline
\end{tabular}

Dari Tabel 2 dapat dilihat dari pre-test, pertanyaan pengetahuan yang sudah dapat dijawab dengan benar oleh seluruh peserta adalah mengenai penularan COVID-19 dan cara menggunakan masker. Dari Tabel 2 juga dapat dilihat bahwa pertanyaan pengetahuan yang belum dapat dijawab dengan benar oleh seluruh peserta adalah pertanyaan mengenai kepanjangan singkatan COVID-19, gejala COVID-19, pembagian wilayah/zona untuk COVID-19, dan jenis masker. Pada post-test didapati hampir seluruh pertanyaan dapat dijawab dengan benar oleh seluruh peserta. Pertanyaan mengenai sikap menunjukkan sikap yang positif terhadap pencegahan penularan COVID-19 baik pre-test dan post-test.
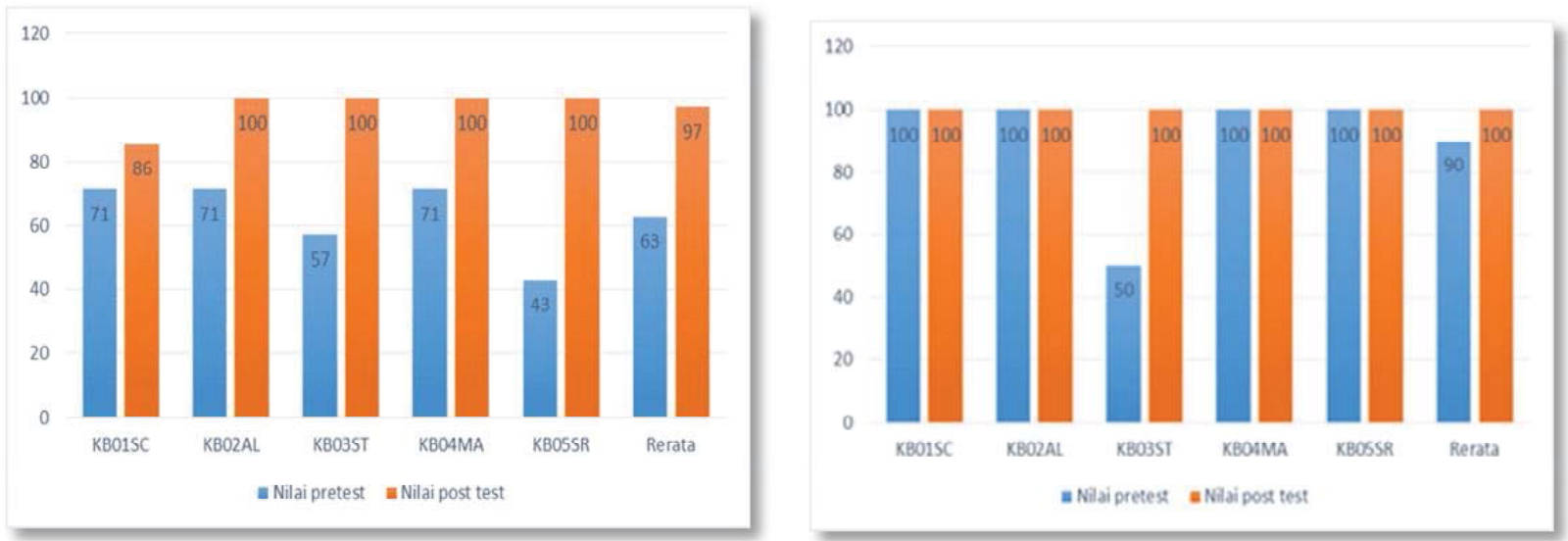

Gambar 4. Peningkatan pengetahuan peserta pre-test dan post-test Gambar 5. Perubahan sikap positif peserta dari pre-test dan post-test 
Program Pencegahan Penularan COVID-19 pada Komunitas Ibu Rumah Tangga dengan HIV di Surabaya

Hanna Tabita Hasianna Silitonga, Etha Rambung, Romauli Nainggolan, Gusto Benyamin Messakh, Keith Justine Thiotansen

Peningkatan pengetahuan dari para peserta dapat dilihat dari Gambar 4. Secara keseluruhan terdapat peningkatan pengetahuan dari nilai pre-test 63 menjadi 97 pada saat post-test. Masih ada peserta yang belum dapat menjawab pertanyaan mengenai kepanjangan COVID-19. Pengetahuan yang meningkat dengan drastis adalah mengenai gejala COVID-19. Para peserta di awal masih berpikir bahwa gejala COVID19 adalah demam dan batuk, sedangkan gejala COVID-19 selain itu juga dapat berupa diare, lemah, bahkan yang berhubungan dengan gejala dan tanda di kulit (Ditjen PP \& PL Kemenkes RI, 2020).

Perubahan sikap peserta sebelum dan sesudah program dapat dilihat dari Gambar 5. Secara umum, baik sebelum dan sesudah program, para peserta memang sudah memiliki sikap yang positif terhadap perilaku pencegahan penularan COVID-19 khususnya tentang menggunakan masker setiap kali keluar rumah dan sering mencuci tangan dengan sabun atau hand sanitizer. Hanya ada satu peserta yang sebelumnya tidak terlalu setuju untuk senantiasa mencuci tangan dengan sabun atau hand sanitizer. Sesudah program, sikapnya berubah menjadi setuju.

Pada pengabdian masyarakat ini menggunakan berbagai metode dan media untuk memberikan pemahaman kepada para peserta yang adalah ibu rumah tangga. Penggunaan media video ataupun poster infografis dapat menghasilkan perubahan pemahaman yang lebih baik daripada sekedar metode ceramah. Hal ini sesuai dengan penelitian Kapti et al. (2013) dimana ditemukan perbedaan yang bermakna pada kelompok ibu rumah tangga yang menggunakan media audiovisual (Kapti et al., 2013). Bahkan terdapat penelitian yang menunjukkan ada pengaruh yang signifikan terhadap pengetahuan dan sikap ibu hamil terhadap persalinan dengan menggunakan media video persalinan berbasis video whatsapp (Kholisotin et al., 2019). Mengenai media poster, menurut penelitian tidak ada perbedaan yang bermakna antara media poster dan media video dalam memberikan pengetahuan (Sholehah et al., 2019). Hal ini menunjukkan kedua media tersebut sama efektifnya digunakan untuk meningkatkan pengetahuan ibu.

\section{Keunggulan dan Kelemahan Program}

Evaluasi dari program ini menunjukkan bahwa terdapat peningkatan pengetahuan dan sikap dari para peserta melalui metode yang digunakan. Hal ini dapat dilihat dari hasil tes peserta sebelum dan sesudah program. Selain itu, dengan menggunakan metode daring, memiliki kelebihan antara lain waktu yang digunakan lebih flexibel karena tidak membutuhkan waktu perjalanan ke lokasi kegiatan. Kegiatan dapat dilakukan di tempat tinggal masing-masing. Hal ini sesuai dengan penelitian Ariadhy et al. (2020) tentang pembelajaran jarak jauh menggunakan daring yang tetap dapat mencapai tujuan pembelajaran secara optimal (Ariadhy et al., 2020). Pemanfaatan WAG dalam mendampingi peserta juga menjadi sarana komunikasi yang baik antara tim dengan peserta. Hal ini sesuai dengan penelitian Sukrillah et al. (2018) bahwa media sosial seperti WAG dapat dimanfaatkan menjadi sarana komunikasi dan diskusi di antara para peserta yang ada didalamnya (Sukrillah et al., 2018). Hal ini juga didukung karena fitur aplikasi whatsapp yang mudah digunakan bahkan oleh ibu rumah tangga. Penelitian Nainggolan et al. (2020) pada ibu rumah tangga menunjukkan bahwa terdapat perbedaan dalam hasil pemasaran dan penjualan produk yang lebih tinggi jika menggunakan WhatsApp dibandingkan dengan media situs web Facebook yang menunjukan penggunaan media whatsapp dapat dikuasai dengan baik oleh respondennya yang adalah ibu rumah tangga (Nainggolan et al., 2020).

Kelemahan dari program ini adalah waktu dan metode yang terbatas untuk dapat mengintervensi perubahan perilaku dari peserta. Perubahan perilaku memerlukan waktu yang cukup lama sampai akhirnya 
ABDIMAS: Jurnal Pengabdian Masyarakat Universitas Merdeka Malang

Volume 5, No 3, November 2020: 193-201

perilaku baru terjadi secara konsisten. Menurut teori transtheoretical, ada berbagai fase dalam perubahan perilaku dan ketika seseorang mulai menunjukkan perilaku baru secara konsisten maka ia termasuk dalam tahap action. Seseorang dapat dikatakan memasuki tahap maintenance yaitu ketika perilaku baru tersebut bertahan sampai setidaknya lebih dari 6 bulan (Glanz et al. 2008). Dalam era adaptasi kebiasaan baru ini, perilaku pencegahan penularan COVID-19 dari para peserta dapat dikatakan berhasil jika terus menerus dilakukan sampai lebih dari 6 bulan.

\section{SIMPULAN DAN SARAN}

\section{Simpulan}

Secara umum program pengabdian masyarakat ini berjalan dengan lancar. Perubahan yang serba cepat terkait pandemi COVID-19 membuat topik ini menjadi topik yang penting untuk diberikan kepada masyarakat terutama ibu rumah tangga dengan HIV agar peserta dapat segera melakukan adaptasi perubahan perilaku yang baru terkait pencegahan penularan COVID-19. Dalam situasi dimana protokol kesehatan harus dilakukan termasuk jaga jarak, maka pembelajaran jarak jauh dengan sistem daring menjadi pilihan. Media yang digunakan adalah seminar dan demonstrasi melalui zoom, pelatihan dan pendampingan melalui WAG dengan menggunakan media poster dan video. Hasil yang diperoleh adalah terdapat peningkatan pengetahuan dan sikap terhadap pencegahan penularan COVID-19 yang dibuktikan dari nilai pre-test dan post-test.

\section{Saran}

Perlu adanya sosialisasi serta promosi mengenai adanya program ini, sehingga peserta tidak hanya berasal dari komunitas Bu'Daya (Ibu Berdaya dengan HIV) saja tetapi juga komunitas Orang dengan HIVAIDS (ODHA) lainnya. Selain itu pendampingan secara berkala perlu terus dilanjutkan mengingat perubahan perilaku tidak terjadi dalam waktu yang relatif singkat tetapi panjang.

\section{Ucapan Terimakasih}

Ucapan terimakasih diberikan kepada Direktorat Riset dan Pengabdian Masyarakat, Direktorat Jenderal Riset dan Pengembangan Kementerian Riset, Teknologi, dan Pendidikan Tinggi yang telah memberikan hibah PKM Komunitas Bu'Daya (Ibu Berdaya dengan HIV) di Surabaya. Terimakasih juga diucapkan untuk LPPM dan Fakultas Kedokteran Universitas Ciputra Surabaya serta para peserta komunitas Bu'daya atas dukungannya sehingga kegiatan ini dapat terselenggara dengan baik.

\section{DAFTAR PUSTAKA}

Ariadhy, S. Y., Nurohman, S., Arkum, D., Handini, W., \& Ferdiana, F. (2020). Pelatihan pembelajaran jarak jauh di era pandemi COVID-19. Anoa Jurnal Pengabdian Masyarakat, 1(3), 220-226. http://dx.doi.org/10.1234/anoa.v1i3.13640

Chenneville, T., Gabbidon, K., Hanson, P., \& Holyfield, C. (2020). The impact of COVID-19 on HIV treatment and research: A call to action. International Journal of Environmental Research and Public Health, 17(12), 4548. https://doi.org/10.3390/ijerph17124548 
Program Pencegahan Penularan COVID-19 pada Komunitas Ibu Rumah Tangga dengan HIV di Surabaya

Hanna Tabita Hasianna Silitonga, Etha Rambung, Romauli Nainggolan, Gusto Benyamin Messakh, Keith Justine Thiotansen

Direktorat Jenderal Pengendalian Penyakit dan Penyehatan Lingkungan. (2016). Pedoman Nasional Penanganan Infeksi Menular Seksual. Jakarta: Kementerian Kesehatan RI.

Ditjen PP \& PL Kemenkes RI. (2020). Pedoman Pencegahan dan Pengendalian Coronavirus Disease (COVID-19) Revisi ke-4. Jakarta: Kementerian Kesehatan RI.

Etienne, N., Karmochkine, M., Slama, L., Pavie, J., Batisse, D., Usubillaga, R., Latembet, V., Brazille, P., Canouï, E., Slama, D., Joumaa, H., Canoui-Poitrine, F., Segaux, L., Weiss, L., Viard, J., \& Salmon, D. (2020). HIV infection and COVID-19: Risk factors for severe disease. AIDS, 34(12), 1771-1774. https://doi.org/10.1097/QAD.0000000000002651

Glanz, K., Rimer, B. K. \& Viswanath, K. (2008). Health Behaviour and Health Education. John Wiley \& Sons.

Kapti, R. E., Rustina, Y., \& Widyatuti, W. (2013). Efektifitas audiovisual sebagai media penyuluhan kesehatan terhadap peningkatan pengetahuan dan sikap ibu dalam tatalaksana balita dengan diare di dua rumah sakit Kota Malang. Jurnal Ilmu Keperawatan, 1(1), 53-60.

Kementerian Kesehatan Republik Indonesia. (2020). Data dan informasi kesehatan indonesia 2019. Profil Kesehatan Indonesia, 8(9), 1-213.

Kholisotin, K., Prasetyo, A. D. \& Agustin, Y. D. (2019). Pengaruh penyuluhan berbasis video whatsapp tentang persalinan terhadap pengetahuan dan sikap ibu hamil trimester III di Puskesmas Klabang Kabupaten Bondowoso. The Indonesian Journal of Health Science, 11(2), 182. https://doi.org/10.32528/ijhs.v11i2.2962

Laurence, J. (2020). Why aren't people living with HIV at higher risk for developing severe coronavirus disease 2019 (COVID-19)? AIDS Patient Care and STDs, 34(6), 247-248. https://doi.org/10.1089/apc.2020.29005.com

Nainggolan, R., Silitonga, H. T. H. \& Rambung, E. (2020). Penggunaan media online untuk bisnis online pemula pada penderita HIV. SHARE "SHaring - Action - REflection", 6(1), 23-27. https://doi.org/10.9744/share.6.1.23-27

Sholehah, M., Kholisotin, K. \& Munir, Z. (2019). Efektifitas pendidikan kesehatan menggunakan media audio visual dan poster terhadap perilaku ibu primipara dalam manajemen laktasi. Citra Delima: Jurnal IImiah STIKES Citra Delima Bangka Belitung, 3(2), 117-127. https://doi.org/10.33862/citradelima.v3i2.67

Silitonga, H. T. H. (2018). Behavior of PLWHA IDU and housewives in preventing HIV/AIDS Transmission. Jurnal Kedokteran Mulawarman, 5(2), 11-22.

Sukrillah, A., Ratnamulyani, I. A., \& Kusumadinata, A. A. (2018). Pemanfaatan media sosial melalui Whatsapp group FEI sebagai sarana komunikasi. Jurnal Komunikatio, 3(2). https://doi.org/10.30997/jk.v3i2.919

WHO. (2020). Transmission of SARS-CoV-2/: Implications for infection prevention precautions. 